JFFI. 2019; 6(1) 334-339

www.jurnal.farmasi.umi.ac.id/index.php/fitofarmakaindonesia

\title{
FORMULASI TABLET HISAP CAMPURAN KATEKIN GAMBIR DAN JAHE DENGAN JENIS PENGIKAT PVP DAN GOM ARAB
}

\author{
Erni Rustiani*, Dwi Indriati, Linda Actia \\ Program Studi Farmasi, FMIPA, Universitas Pakuan \\ "ernirustiani@unpak.ac.id
}

Submission Date: 06-01-2019; $\quad$ Review Completed: 12-01-2019; $\quad$ Accepted Date: 23-01-2019

\begin{abstract}
ABSTRAK
Gambir mempunyai kemampuan dapat membunuh ataupun menghambat pertumbuhan bakteri. Jahe memiliki kandungan flavonoid dan gingerol yang mempunyai aktivitas antibakteri untuk mulut dan gusi. Penelitian ini bertujuan untuk membuat sediaan tablet hisap kombinasi katekin gambir dan jahe dengan variasi jenis pengikat PVP dan Gom arab. Hasil penelitian menunjukkan bahwa formula terbaik dari setiap jenis pengikat yaitu formula dengan pengikat gom arab $10 \%$ dan formula dengan pengikat PVP K-30 7\%. Berdasarkan kemudahan dalam proses granulasi dipilih formula dengan konsentrasi PVP K-30 7\% sebagai formula terbaik dengan hasil rata-rata keseragaman bobot tablet 2,0406 $\mathrm{g}$, ukuran tebal $58,9 \mathrm{~mm}$, diameter 21,95 mm, kekerasan 23,63 kp, friabilita 0,14\% dan waktu hancur 28 menit 62 detik. Hasil pengujian kadar flavonoid total terhadap ekstrak kering jahe sebesar $2,71 \%$ dan sediaan tablet hisap 2,32\%.
\end{abstract}

Keywords: Katekin Gambir, Jahe, Tablet Hisap, PVP, Gom arab

\section{PENDAHULUAN}

Halitosis adalah suatu istilah umum yang digunakan untuk menerangkan adanya bau yang tidak disukai sewaktu terhembus udara. Halitosis merupakan penyakit yang banyak di jumpai, berdasarkan Riskesdas tahun 2007 dan 2013, persentase penduduk Indonesia yang mempunyai masalah gigi dan mulut meningkat dari 23,2\% menjadi $25,9 \%$ dan di antara masalah kesehatan mulut tersebut adalah bau mulut (Kemenkes RI, 2014). Halitosis berat dapat mengganggu kenyamanan orang lain saat berinteraksi sosial, mempengaruhi rasa percaya diri dan mengurangi performa pada saat berinteraksi sosial (Hakim, 2013).

Gambir mempunyai kandungan terbanyak fenol dan katekin. Kemampuan bakterisidal katekin dengan cara mendenaturasi protein dari bakteri, dapat membunuh ataupun menghambat pertumbuhan bakteri (Hayani, 2003). Penelitian tentang ekstrak katekin gambir sebagai antibakteri menunjukkan bahwa katekin gambir mempunyai sifat penghambatan bakterisidal (membunuh bakteri) terhadap bakteri Streptococcus mutans, Staphylococcus aureus dan Bacillus subtillis. Pemberian 4\% katekin sudah cukup menyebabkan kematian ketiga bakteri dan penambahan ekstrak katekin $6 \%$ dapat mematikan $100 \%$ S.mutans dan S.aureus dalam waktu 1 jam (Pambayun et al, 2008).
Jahe (Zingiber officinalis Roxb) merupakan salah satu tanaman obat tradisional yang mempunyai rasa yang sangat pedas tetapi akan berasa segar jika berada lama dalam mulut dan tenggorokan (Syamsuhidayat dan Hutapea, 1991). Salah satu kandungan dari jahe yaitu gingerol dan flavonoid. Gingerol mempunyai aktivitas antibakteri untuk mulut dan gusi (Miri, Bae dan Lee, 2008). Flavonoid bersifat sebagai antibakteri dan antifungi sehingga dimanfaatkan sebagai obat antibiotik alamiah (Duke, 2000). Menurut penelitian terbukti bahwa ekstrak etanol rimpang dapat menghambat pertumbuhan bakteri Staphylococcus aureus dengan Minimum Inhibitory Concentration (MIC) 12,5\% dengan zona hambat 7,1 mm (Yanotama, 2008).

Sehingga dilakukan pembuatan tablet hisap dengan menggunakan katekin gambir dan jahe sebagai obat halitosis. Kombinasi kedua tanaman tersebut yaitu untuk mendapatkan manfaat yang lebih baik. Katekin merupakan senyawa yang memiliki rasa pahit sehingga digunakan jahe untuk memperbaiki rasa. Salah satu eksipien yang penting digunakan pada tablet hisap adalah zat pengikat. Zat pengikat yang digunakan berupa PVP K-30 dan Gom arab. Penggunaan pengikat yang berbeda bertujuan untuk mengetahui pengikat yang lebih baik dalam formulasi tablet hisap. Granul dengan pengikat PVP K-30 dan Gom arab memiliki sifat alir yang baik, sudut diam minimum, menghasilkan fines lebih 
sedikit dan daya kompaktibilitasnya lebih baik (Banker dan Anderson, 1994). Penggunaan PVP K30 pada konsentrasi $10 \%$ pada pembuatan tablet hisap ekstrak gambir dapat menghasilkan tablet hisap yang mempunyai kekerasan yang cukup, kerapuhan yang rendah dan waktu hancur yang lama (Hana, 2010). Pemberian gom arab pada konsentrasi $20 \%$ menghasilkan tablet hisap ekstrak gambir dengan kekerasan yang baik (Luthfi dkk, 2010)

\section{METODE PENELITIAN}

\section{A. Alat dan Bahan}

Alat yang digunakan dalam penelitian ini meliputi , alat uji kadar air (Moisture balance - MX50), alat uji sifat alir, media cetak tablet (Rimex), alat uji kekerasan tablet (Hardness tester - YD-3), alat uji kerenyahan tablet (Friabillator tester - Omron H3BA), alat uji waktu hancur (Desintegration tester - Shimadzu BJ-2), neraca analitik, oven, vaccum dryer (Labonco) dan alat-alat gelas standar laboratorium lainnya.

Bahan baku yang digunakan dalam penelitian ini adalah katekin gambir yang diperoleh dari Universitas Andalas, jahe diperoleh dari perkebunan Tegalega (Bogor), Etanol 96\%, Maltodekstrin, Manitol, Magnesium stearat, Talk, Polivinil pirolidon (PVP K-30), PEG 6000, akuades, serbuk mint, gom arab, laktosa.

\section{B. Pembuatan Ekstrak Kering Jahe}

Pembuatan ekstrak jahe menggunakan pelarut etanol $96 \%$. Ekstrak jahe dibuat dengan memasukan serbuk kering simplisia jahe sebanyak 1 $\mathrm{kg}$ ke dalam maserator, kemudian ditambahkan 10 liter pelarut etanol 96\%. Campuran direndam selama 6 jam pertama sambil sekali-sekali diaduk, kemudian didiamkan selama 18 jam. Maserat dipisahkan dengan cara pengendapan. Proses penyarian diulangi sekurang kurangnya dua kali dengan jenis dan jumlah pelarut yang sama. Semua maserat yang dikumpulkan kemudian ditambahkan bahan pengisi maltodekstrin sebanyak 300 gram dan diaduk hingga homogen. Maserat dikeringkan di dalam oven vakum dengan suhu $60^{\circ} \mathrm{C}$ dan dihaluskan dengan blender dan diayak. Ekstrak kering jahe dihitung rendemennya. Uji mutu ekstrak kering jahe meliputi uji kadar air dan kadar abu. Uji fitokimia ekstrak jahe meliputi alkaloid, flavonoid, tanin dan polifenol, saponin, serta steroid dan terpenoid (DepKes RI, 1989).

\section{Penentuan Kadar Flavonoid Total Ekstrak Kering Jahe}

Ekstrak kering jahe ditimbang sebanyak $100 \mathrm{mg}$ dan dimasukkan kedalam labu $50 \mathrm{ml}$. Ekstrak dilarutkan dengan pelarut metanol dalam labu $50 \mathrm{ml}$. Campuran dikocok selama 10 menit sampai larut. Larutan ekstrak jahe dipipet sebanyak $1 \mathrm{ml}$ kemudian dimasukkan ke dalam

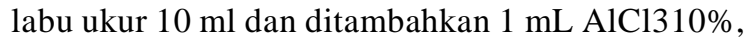
$1 \mathrm{~mL} \mathrm{Na}$ Asetat $1 \mathrm{M}$ dan air suling sampai batas. Larutan dikocok hingga homogen dan dibiarkan selama waktu optimum 25 menit. Serapan diukur pada panjang gelombang maksimal $430 \mathrm{~nm}$. Absorban yang dihasilkan dimasukkan kedalam persamaan regresi dari kurva standar kuersetin, kemudian dihitung kadar flavonoid total (Chang et $a l, 2002)$.

\section{Pembuatan Tablet Hisap}

Tablet hisap dibuat sebanyak 4 formula dengan pengikat PVP dan gom arab. Setiap formula dibuat sebanyak 300 tablet dengan berat tiap tablet 2 gram (Tabel 1).

Tabel 1. Formula Tablet Hisap

\begin{tabular}{ccccc}
\hline & \multicolumn{5}{c}{ Konsentrasi bahan (\%) } \\
\cline { 2 - 5 } Nama bahan & $\mathbf{1}$ & $\mathbf{2}$ & Formula & $\mathbf{3}$ \\
\hline Katekin Gambir & 3 & 3 & 3 & 3 \\
Ekstrak Jahe & 3 & 3 & 3 & 3 \\
Gom arab & 7,5 & 10 & - & - \\
PVP K-30 & - & - & 5 & 7 \\
Sukralosa & 0,5 & 0,5 & 0,5 & 0,5 \\
Talk & 1 & 1 & 1 & 1 \\
Mg Stearat & 2 & 2 & 2 & 2 \\
Campuran manitol dan & 100 & 100 & 100 & 100 \\
laktosa (1:1) ad & & & & \\
\hline
\end{tabular}

Pembuatan tablet hisap diawali dengan penimbangan semua bahan dan pengayakan dengan mesh 40. PVP K-30 dan gom arab dilarutkan dalam akuades sebagai larutan pengikat. Ekstrak kering jahe dan gambir ditambahkan manitol, sukralosa, dan larutan pengikat sampai terbentuk massa granul yang kompak. Massa granul yang diperoleh kemudian diayak menggunakan ayakan mesh 8 . Granul basah 
dikeringkan dalam oven blower selama 30 menit dengan suhu $40^{\circ} \mathrm{C}$. Granul kering yang diperoleh diayak kembali dengan menggunakan pengayak mesh.12 dan ditambahkan talk dan Mg stearat hingga homogen. Evaluasi granul yang dilakukan meliputi uji kadar air, uji daya alir, dan uji kompresibilitas. Selanjutnya massa granul dicetak menjadi tablet menggunakan mesin pencetak alat tablet, kemudian dilakukan evaluasi tablet meliputi uji penampilan, keseragaman bobot, keseragaman ukuran, uji kekerasan, dan uji friabilita.

\section{E. Penentuan Kadar Flavonoid Total Tablet Hisap}

Sebanyak 5 tablet ditimbang lalu digerus menjadi serbuk tablet yang halus. Serbuk yang dihasilkan ditimbang setara dengan kandungan jumlah ekstrak $100 \mathrm{mg}$, dimasukkan ke dalam labu ukur $50 \mathrm{~mL}$ dan ditambah metanol hingga batas. Larutan diaduk menggunakan magnetic stirrer selama 20 menit lalu disaring. Larutan dipipet sebanyak $1 \mathrm{ml}$ dimasukkan ke dalam labu ukur 10 $\mathrm{ml}$ dan ditambah $1 \mathrm{~mL} \mathrm{AlCl}_{3} 10 \%, 1 \mathrm{~mL}$ Natrium dan ditambahkan dengan aquadest sampai tanda batas. Larutan dikocok hingga homogen lalu disimpan selama waktu optimum 25 menit. Serapan diukur pada panjang gelombang maksimal $430 \mathrm{~nm}$. Absorban yang dihasilkan dimasukkan kedalam persamaan regresi dari kurva standar kuersetin, kemudian dihitung kadar flavonoid total.

\section{HASIL DAN PEMBAHASAN}

Serbuk simplisia jahe memiliki warna kuning kecoklatan, bau aromatik dan rasa pedas (Gambar 1).

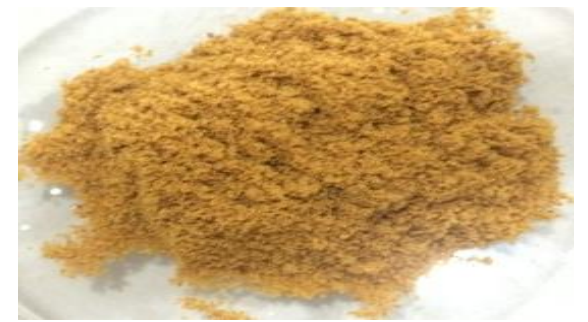

Gambar 1. Ekstrak Kering Jahe

Kadar air ekstrak kering jahe 5\%, sesuai dengan persyaratan $\leq 10 \%$ sedangkan kadar abu $1,15 \%$ sesuai persyaratan $\leq 7,8 \%$ (DepKes RI, 2008).

Pengujian fitokimia merupakan suatu metode kimia yang digunakan untuk mengetahui senyawa metabolit sekunder yang terkandung dalam ekstrak. Serbuk ekstrak kering jahe positif mengandung senyawa metabolit sekunder berupa senyawa flavonoid, alkaloid, tanin dan saponin. Hasil uji fitokimia sama dengan penelitian sebelumnya yang menyatakan bahwa ekstrak jahe mengandung terpenoid, saponin, tanin, flavonoid dan alkaloid (Khalidah, 2014).

\section{Analisis Kadar Flavonoid Ekstrak jahe}

Hasil serapan maksimum yang diperoleh adalah $430 \mathrm{~nm}$ dengan waktu inkubasi optimum yang diperoleh adalah 25 menit. Persamaan regresi y = $0,0837 \mathrm{x}-0,0158$, dengan koefisien korelasi $\mathrm{r}=$ 0,9998 berarti grafiknya linear dan adanya hubungan antara absorbansi dan konsentrasi. Berdasarkan perhitungan regresi linear diperoleh kadar flavonoid total pada ekstrak jahe sebesar $2,71 \%$.

\section{Hasil Evaluasi Granul}

Sebelum dicetak massa granul tablet hisap dilakukan evaluasi granul untuk mengetahui kualitas granul dengan melakukan pengujian kadar air, sifat alir, dan kompressibilitas (Tabel 3).

Tabel 3. Kadar air, uji alir, kompresibilitas granul

\begin{tabular}{|c|c|c|c|c|c|}
\hline \multirow[b]{2}{*}{ Parameter } & \multicolumn{4}{|c|}{ Formula } & \multirow[b]{2}{*}{ Syarat } \\
\hline & $\begin{array}{c}1 \\
(\text { Gom arab } \\
7,5 \%)\end{array}$ & $\begin{array}{c}2 \\
(\text { Gom arab } \\
10 \%)\end{array}$ & $\begin{array}{c}3 \\
\text { (PVP 5\%) }\end{array}$ & $\begin{array}{c}4 \\
(\text { PVP 7\%) }\end{array}$ & \\
\hline Kadar air (\%) & 2,1871 & 2,1223 & 2,8435 & 2,0199 & $\leq 5 \%$ \\
\hline Uji alir (g/det) & $\begin{array}{c}9,7579 \\
\text { (Mudah } \\
\text { mengalir) }\end{array}$ & $\begin{array}{c}10,3018 \\
\text { (Bebas } \\
\text { mengalir) }\end{array}$ & $\begin{array}{c}9,0339 \\
\text { (Mudah } \\
\text { mengalir) }\end{array}$ & $\begin{array}{c}9,6786 \\
\text { (Mudah } \\
\text { mengalir) }\end{array}$ & $\begin{array}{c}4-10 \\
\text { (Mudah } \\
\text { Mengalir) }\end{array}$ \\
\hline $\begin{array}{c}\text { Kompresibilitas } \\
(\%)\end{array}$ & $\begin{array}{c}3,2623 \\
\text { (sangat baik } \\
\text { sekali) }\end{array}$ & $\begin{array}{c}3,4470 \\
\text { (sangat baik } \\
\text { sekali) }\end{array}$ & $\begin{array}{c}2,7524 \\
\text { (sangat baik } \\
\text { sekali) }\end{array}$ & $\begin{array}{c}2,5275 \\
\text { (sangat baik } \\
\text { sekali) }\end{array}$ & $\begin{array}{c}5-12 \\
\text { (sangat baik } \\
\text { sekali) }\end{array}$ \\
\hline
\end{tabular}


Hasil evaluasi granul menunjukkan bahwa formula granul memiliki kadar air yang memenuhi syarat. Pengujian kadar air granul dilakukan untuk mengetahui kandungan air yang tersisa dalam granul setelah proses pengeringan. Hasil kadar air granul pada masing- masing formula memenuhi syarat kadar air granul yaitu kelembaban granul idealnya 2-5\% (Voigt, 1994).

Hasil laju alir pada formula 1 lebih kecil dibandingkan formula 2 begitupula dengan formula 3 dan 4. Semakin besar konsentrasi pengikat yang digunakan akan memperbesar kerapatan granul sehingga waktu alirnya akan semakin singkat. Formula dengan laju alir yang paling baik adalah formula 2 menggunakan pengikat gom arab $10 \%$.

Uji kompresibilitas bertujuan untuk menentukan sifat bahan untuk membentuk massa yang stabil dan kompak bila diberi tekanan. Hasil uji kompresibilitas semua formula menyatakan sangat baik sekali, karena PVP K-30 dan Gom arab mempunyai kemampuan yang besar dalam mengikat partikel-partikel serbuk menjadi satu kesatuan sehinga membentuk granul yang kuat dan menghasilkan kompresibilitas yang baik.

\section{Hasil Evaluasi Tablet}

Evaluasi tablet dilakukan untuk mengetahui mutu fisik tablet dengan melakukan pengujian tehadap beberapa parameter yaitu penampilan tablet, keseragaman bobot, keseragaman ukuran, kekerasan, friabilita dan waktu hancur tablet (Tabel 4).

Penampilan tablet pada masing-masing formula diuji secara organoleptik berupa warna, bau, bentuk dan rasa. Tablet yang dihasilkan berwarna coklat muda dengan permukaan atas dan bawah rata, bau khas aromatik ekstrak dan rasa pedas agak pahit (Gambar 2).

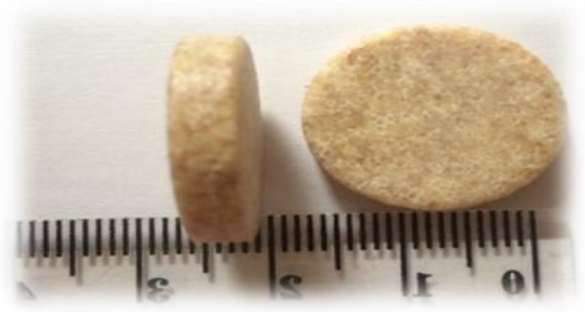

Gambar 2. Tablet Campuran Katekin Gambir dan Ekstrak Jahe

Tabel 4. Hasil Keseragaman bobot, keseragaman ukuran, kekerasan, friabilita, dan waktu hancur tablet

\begin{tabular}{|c|c|c|c|c|c|}
\hline \multirow{2}{*}{ Parameter } & \multicolumn{4}{|c|}{ Formula } & \multirow{2}{*}{ Syarat } \\
\hline & 1 & 2 & 3 & 4 & \\
\hline Keseragaman Bobot (g) & 2,0514 & 2,0298 & 2,0588 & 2,0406 & $\begin{array}{l}\text { Tidak boleh ada } 2 \\
\text { tablet yang } \pm 5 \% \text { dan } \\
\pm 10 \% \\
\text { (Depkes RI, 1979) }\end{array}$ \\
\hline Keseragaman Ukuran (mm) & $\begin{array}{l}\mathrm{t}: 5,675 \\
\mathrm{~d}: 21,75\end{array}$ & $\begin{array}{c}\text { t: } 5,88 \\
\text { d: } 21,85\end{array}$ & $\begin{array}{l}\text { t: } 5,885 \\
\text { d: } 21,9\end{array}$ & $\begin{array}{c}\text { t: } 5,89 \\
\text { d: } 21,95\end{array}$ & $\begin{array}{l}\text { Diameter } \geq 18 \mathrm{~mm} \\
\text { (Voigt,1994) }\end{array}$ \\
\hline Kekerasan (kp) & 14,14 & 17,32 & 20,32 & 23,63 & $\begin{array}{l}\text { 10-20 kp } \\
\text { (Parrot,1971) }\end{array}$ \\
\hline Friabilita $(\%)$ & 0,3552 & 0,1328 & 0,2373 & 0,1421 & $\begin{array}{l}\leq 1 \% \\
\text { (Lachman dan } \\
\text { Lieberman, 1994) }\end{array}$ \\
\hline Waktu Hancur (menit.detik) & $21 ’ 21 ”$ & $23{ }^{\prime} 06^{\prime \prime}$ & $25^{\prime} 01^{\prime \prime}$ & $28^{\prime} 62^{\prime \prime}$ & $\begin{array}{l}30 \text { menit atau kurang } \\
\text { (Lachman, 1994) }\end{array}$ \\
\hline
\end{tabular}

Keterangan: t(tebal) d (diameter)

Hasil pengujian keseragaman bobot dan ukuran memenuhi syarat. Penggunaan pengikat PVP K-30 dan gom arab keduanya menghasilkan tablet yang kompak dan mudah dicetak sehingga keseragaman bobot dan ukuran tablet menjadi seragam. Keseragaman bobot dan ukuran tablet berpengaruh terhadap penampilan fisik tablet, sehingga lebih disukai konsumen.
Uji kekerasan tablet bertujuan untuk mengetahui kekerasan tablet yang dihasilkan karena tablet harus keras agar kuat dan tahan ketika proses distribusi. Syarat kekerasan tablet hisap adalah 10$20 \mathrm{~kg} / \mathrm{cm} 2$ (Parrot, 1971). Hasil uji kekerasan formula 1 dan 2 (pengikat gom arab) lebih rendah tingkat kekerasannya dibandingkan dengan formula 3 dan 4 (pengikat PVP K-30). PVP K-30 merupakan pengikat sintetis yang memiliki kemampuan 
mengikat serbuk lebih kuat dibandingkan gom arab yang merupakan jenis pengikat bahan alam. Semakin tinggi konsentrasi setiap pengikat maka semakin tinggi tingkat kekerasan tablet. Kekerasan tablet keempat formula memenuhi syarat, namun jika tablet berada di tempat terbuka terlalu lama maka tablet akan melunak. Sifat dari PVP dan gom arab serta manitol dan laktosa adalah higroskopis. Kekerasan tablet mempengaruhi kerapuhan dan waktu larut tablet, semakin tinggi kekerasan tablet akan semakin rendah presentase kerapuhan dan semakin lama waktu larutnya.

Uji friabilita dilakukan untuk mengetahui ketahanan dan kerapuhan tablet yang dihasilkan karena tablet harus kuat dan tahan oleh gesekan yang terjadi pada saat distribusi dengan menghitung banyaknya bobot tablet yang hilang selama pengujian. Hasil pengujian friabilita dari keempat formula memenuhi syarat tidak lebih dari $1 \%$ (Lachman, 1994). Semakin tinggi konsentrasi pengikat maka semakin rendah persentase friabilitanya.

Tablet hisap dirancang agar tidak mengalamin kehancuran didalam mulut, tetapi larut atau terkikis secara perlahan-lahan dalam jangka waktu 30 menit atau kurang (Lachman, 1994). Hasil waktu hancur tablet hisap dari keempat formula memenuhi syarat yaitu kurang dari 30 menit dan melebihi waktu hancur tablet biasa yaitu kurang dari 15 menit (DepKes RI, 1995) Formula dengan pengikat gom arab kekerasannya lebih rendah dibandingkan dengan pengikat PVP K-30 karena gom arab merupakan jenis pengikat alami sedangkan PVP K-30 jenis pengikat sintetis. Berdasarkan kemudahan dalam proses granulasi maka dipliih formula 4 (PVP K-30 7\%) yang terbaik.

Hasil penetapan kadar flavonoid total tablet (Tabel 5) diperoleh kadar flavonoid ekstrak jahe sebesar $2,71 \%$. Kadar flavonoid dalam sediaan tablet mengalami penurunan bila dibandingkan ekstrak murni. Tablet formula 2 memiliki kadar flavonoid $1,88 \%$ dengan penurunan kadar $30,59 \%$ sedangkan tablet formula 4 mengandung 2,32\% dan mengalami penurunan kadar $14,20 \%$. Penurunan kadar formula 2 lebih besar dibandingkan formula 4 karena saat proses granulasi formula 2 menghasilkan massa granul yang lebih lengket sehingga menyulitkan proses pengayakan granul dan banyak massa yang menempel pada ayakan.

\section{KESIMPULAN}

1. Katekin gambir dan ekstrak jahe dapat dibuat tablet hisap dengan menggunakan pengikat PVP K-30 atau gom arab.
2. Formula 4 (PVP K-30 7\%) memiliki kemudahan pada proses granulasi dan memiliki kualitas yang baik.

3. Kadar flavonoid total ekstrak kering jahe 2,71\%, sediaan tablet hisap formula 2 sebesar $1,88 \%$ dan tablet hisap formula 4 sebesar $2,32 \%$

\section{DAFTAR PUSTAKA}

Banker, G.S., dan Anderson, N.R., 1994. Teori dan Praktek Farmasi Industri, diterjemahkan oleh Siti Suyatmi, Jilid II. UI Press: Jakarta.

Chang, C., Yang, M., When, H., and Chern, J. 2002. Estimation of Total Content in Propolis by Two Complementary Colorimetric Methods. Journal of Food and Drug Analysis. 178-182

Departemen Kesehatan RI, 1989. Materia Medika Indonesia, Jilid V. Direktorat Jenderal Pengawasan Obat Dan Makanan, Jakarta. Hal 116-119.

Departemen Kesehatan RI. 1995. Farmakope Indonesia, Edisi IV. Direktorat Pengawasan Obat dan Makanan. Departemen Kesehatan Republik Indonesia. Jakarta.

Departemen Kesehatan RI. 2008.Farmakope Herbal Indonesia Edisi I. Direktorat Pengawasan obat dan Makanan: Jakarta. Hal 25-28

Duke, James A. 2000. Handbook of Medicinal Herbs. United State of America: CRC Press.: Hal 327-328.

Hakim L. 2013. Penyebab Bau Mulut dan Cara Mengatasi Bau Mulut. http://www.ahlisyukur.com/2013/05/5penyebab-bau-mulut-dan-cara mengatasi.html. Diakses 7 november 2016. 10:36 PM.

Hayani, E. 2003. Analisis Kadar Catechin dari Gambir Dengan Berbagai Metode. Jurnal, vol. 8 . No 1.

Kemenkes RI. 2014. Situasi Kesehatan Gigi dan Mulut. Pusdatin: Jakarta Selatan. Hal 1.

Khalidah, Y. 2014. Formulasi Tablet Effervescent Jahe Dengan Variasi Konsentrasi Sumber Asam dan Basa. Fakultas MIPA: Universitas Tadulako.

Lachman, H. dan J. Lieberman. 1994. Teori dan Praktek Farmasi Industri. Terjemahan dari Teory and Practice of Industrial Pharmacy Oleh Siti Suyatmi, J. Kawira, Lis Aisyah. Jakarta: UI Press.

Luthfi, Asih, dkk. 2010. Formulasi Tablet Hisap Ekstrak Gambir (Uncaria gambir (Hunter) Roxb.) Dengan Variasi Bahan Pengikat Gom Arab (Gummi Acaciae). Farmasi FMIPA UII: Yogyakarta. 
Miri, P., J. Bae dan D.S. Lee. 2008. Antibacterial activity of gingerol and gingerol isolated from ginger rhizome against periodontal bacteria. Phytothery Res. Vol 22, issue 11, p. 1446-1449.

Nailul Hana. 2010. Formulasi Tablet Hisap Dengan Variasi Konsentrasi Polyvinyl Pyrrolidone Sebagai Pengikat dan Pengaruhnya Terhadap Kadar CD4 Dalam Darah. Skripsi. UIN Syarif Hidayatullah: Jakarta. Hal 44-45

Pambayun, R. G, Mudijati. S, Slamet dan R.K, Kapti. 2008. Sensitivitas Bakteri Gram Positif Terhadap Katekin yang Diekstraksi Dari Gambir (Uncaria gambir). Agritech, Vol 28, No 4.

Parrot, E. Z. 1971. Pharmaceutical TechnologyFundamental Pharmaceutics. The United Stated of America: Burgess Publishing Company. Hal 82.

Syamsuhidayat, S.S., dan Hutapea, J.R., 1991, Inventaris Tumbuhan Obat Indonesia I, Departemen Kesehatan RI, Badan Penelitian dan pengembangan: Jakarta. Hal 1.

Voigt, Rudolf. 1994. Buku Pelajaran Teknologi Farmasi Edisi $V$. Gadjah Mada University Press. Yogyakarta. 171-173, 219-226

Yanotama, H. D., 2008. Analisis Komponen Antibakteri Ekstrak Etanol Rimpang Jahe (Zingiber officinale Rosc.) terhadap Bakteri S. aureus dan E. coli dan Bioautografinya, Skripsi, Fakultas Farmasi, Universitas Muhammadiyah Surakarta, Surakarta. 